\title{
A Study of Stress Reduction Through PMR and Talk therapy Among College Students \\ Nikhil Chaudhary ${ }^{1}$, Dr. Tarun Kumar Sharma ${ }^{2}$
}

${ }^{1} \mathrm{PhD}$ Scholar, Department of Psychology, Mohanlal Sukhadia University, Udaipur, Rajasthan, India

${ }^{2}$ Supervisor, Department of Psychology, Mohanlal Sukhadia University, Udaipur, Rajasthan, India

\begin{abstract}
Stress refers to the situation of excess or deficit of one's resources in certain circumstances. The state of stress is very much common among students, especially college going students who had to deal with numerous stressors in their daily lives. To conquer such stressful situation, counseling and its related intervention programme plays a vital role. Counseling refers to a systematic and professional relationship between a professional (Counselor or Psychologist) and a sufferer (Client) in which several techniques are collectively applied to resolve client's stressful issues. The aim of this research is to study the level of stress reduction with the help of PMR and Talk therapy among college students. A standardized stress scale namely 'Perceived Stress Scale' develop by Sheldon Cohen which is possessing high reliability and validity was conducted on 60 college students. Out of them, 30 students were in control and 30 were in experimental group. Furthermore, it was found that students belonging to experimental group were given a proper counseling programme of 5 sessions including PMR and Talk therapy and this result in significant difference at 0.01 level and ultimately leads to reduced stress level as compared to control group. It was found that there is a there is a positive relationship between PMR \& Talk therapy and stress reduction of college students.
\end{abstract}

Keywords : Stress, Counseling, Counselor, Psychologist, Progressive Muscle Relaxation (PMR), Talk therapy.

\section{INTRODUCTION}

\section{Stress}

As far as psychology is concerned, stress is a feeling of anxiety and burden or a kind of psychological pain. Initial amount of stressors mat be desired, healthy or even beneficial but going beyond a limit of stress turned it into a threat. Stress refers to the burden or tension. According to Dr. Hans Selye, "Stress is the non-specific reaction of the body to any demand made upon it."
Stress is the body's manner of reacting to any kind of demanding or threatening situation. When one senses the dangerous stressor, his/her body gear up the defense mode in a rapid and automatic way to respond to the stress. The reaction one make out of stress is the frame's way of shielding itself from the stressors. It helps to stay alert, focused and energetic. Fight or flight responses states that when an individual feels threatened, his/her nervous system responds by discharging a large amount of stress hormones such as adrenaline and cortisol which prepares the body to make the emergency actions 
(fight or flight). Some other reactions to stress are faster heart beats, tighten muscles, rise in blood pressure, unease with breathing and sharpen one's senses. It too enhances one's physical strength, stigma, reaction time, and focus which ultimately prepare him/her to have either fight or flight responses.

The major effects of stress are; if one tends to get anxious normally, then his/her physical and mental body mostly remains within the heightened state of stress which will ultimately lead to severe health issues. Each and every system of the body gets disturbs because of the stress which is chronic in nature. Chronic stress destroys the immune system, lowers down the digestive ability and increases the risk of heart attack $\mathrm{n}$ stroke and also speed up the aging process. It too contributes to the mental health issues like anxiety, depression etc.

Stress when goes beyond a limit leads to health problems. Some of them are sleep problems, body ache, weight problems, reproductive issues, heart disease, skin problems (eczema), autoimmune diseases, digestive problems, depression, anxiety, thinking and memory problems etc.

The most hazardous thing regarding stress is that an individual can easily get affected with it in no time. Even he/she becomes familiar to the stressors and gets it into their routine. Primarily anindividual has no idea that stress is distressing him/her. That is why it is necessary to be aware about the warning bells i.e. the signs and symptoms of overloaded stress.

\section{Major Stressors among College Students}

\section{Academic Stress}

It includes:

- Attending classes, completing the readings, writing papers, managing projects, and preparing for exams all put a heavy burden on students. Numerous students complain of professors or Lecturers who allocatea large amount of work that they must believe theirs is the only class students are taking.

- For new college students, the sudden amount of free time - class that only meet two or three times a week for an hour or so - leads to the advancement of awfullifestyle and habits that can harm academic performance and amplify stress levels.

\section{Personal Stress}

It includes:

- College is a time for transitions, and the transition to adulthood may be a hard one for some of the college students. Some students come to terms with troubles of sexual orientation, spiritual ideals, and different deep problems.

- One may also face roommate issues and peer pressure to take part in all sorts of activities. Some of them may make new friends and significant others who demand one's time.

- +There is also one's self-image which includes social, physical and academic factors and that can be another major stressor.

- Female students, especially, deal with stress related to weight gain and physical appearance, but all students deal with the stress of how they are perceived. And sometimes it's a vicious cycle; because some students are "stress eaters," so while being stressed about their body they actually eat to deal with the stress.

- Finally, there is the rampant use of alcohol and other drugs on many college campuses.

\section{Family Stress}

It includes:

Most students go off to college carrying certain expectations from their families. The pressure to choose the right major and get good grades can be immense and if he/she the first person from his/her family to attend college, the stress is even greater.

Students may also face the stress of family dynamics. Some college students are too dependent on their 
families - going home each weekend -- whilst others are seeking some distance to develop into the person they need to turn out to be.

Experts expect family stress to continue, especially with the increasing occurrence of so-called helicopter parents -- those parents (usually baby boomers) who are so involved in their children's lives that they are in almost constant contact.

\section{Financial Stress}

It includes:

- There's no question that college costs continue to rise, placing increasing pressure on both students and their families to find a way to foot the bill.

- About two-thirds of all college students have student loan debt, with an average 19 lakh student loan debt load for graduating college seniors nationwide. And while 19 lakh may seem like a lot, considering that public college costs an average of about 9 lakh a year and private schools costs 25 lakh, the debt load could undoubtedly be much higher -- and is even higher for some college students to pay.

- There are also a lot of other hidden costs related to college, such as books and school supplies, cell phones, personal care and clothing purchases, items to decorate dorm accommodation,societal outings, charges for joining diverse student clubs and associations, and miscellaneous charges and tickets.

- Besides the stress of having to have the financial resources to pay all these bills, some college students also work part-time -- either through work-study in college or with a local employer. Since working time takes away from studytime, the need to work also leads to stress.

\section{Future Stress}

It includes:

- While attending college is about learning and becoming better educated, it is, of course, also about preparing you for a future career and students who have yet to choose a key or career pathwayexperience incremental levels of stress as every semester passes with no clear solution.

- Additional stress comes from wanting a better life than one's parents, but because the baby boom generation has been one of the most successful, there's even more stress in attempting to do so.

- Many students seem to want to avoid the future by taking what we call the "Peter Pan Syndrome," in which an individual goes to great lengths to avoid any kind of discussions about the future (and growing up).

\section{Signs and Symptoms of Stress among Students}

There are numerous stressors revolves around a college student, the only difference is how one perceive and tackle it. Some of the common signs and symptoms of growing stress among college students are here under:

- High levels of anxiety

- Harming yourself

- Constant headaches

- Feelings of depression

- Difficulty making connections

- Too much -- or not enough -- sleep

- Abuse of alcohol/drugs

- Lingering illnesses and aches and pains

- High levels of irritability, mood swings

- Over-eating or under-eating

\section{Counseling}

Counseling is a professional association that enables diverse individuals, families and groups to achieve mental health, wellness, education and career goals. The basic purpose of counseling is to support individuals in using their present problem-solving abilities more efficiently or to improve new or better coping skills. It is not a counselor who fixes other people's problem. His work is just to provide a fair opportunity for the individual (client) to describe 
their feelings and problems for themselves and then to reach to the conclusions and actions that are based on informed choices.

A good counselor or a counselor with good counseling skills supports people in building those skills which they can use in resolving their problems. For instance, if an individual learns good communication skills to deal with their spouses, then he/she can use those skills with his/her friends, children and co-workers. This simply means positive transfer of learning which benefits the individual.

As far as the process of counseling is concerned, it has a process which works at the beginning, middle and at the end and counselor plays a vital role in each of its part.

The beginning: The counselor begins to form a trusting relationship with the client and finds out significant information about the client's problem. This is technically termed as 'rapport formation'.

The middle: the counselor helps the client to set appropriate and attainable goals and also helps the client to make assessment regarding what he/she wants. After deciding the goals, both the client and the counselor develop ideas regarding the pathways to reach those goals. In this duration, client tries several methods and also discusses it with the counselor to get the correct method to reach the goal.

The end: When the client has achieved the predecided goal then it is the time for the counselor to terminate the counseling relationship.

Counselingand therapy offer a range of positive benefits which can improve one's life. When a person try and discover his/her thoughts with a professional, he/she feels less aloof and is able to sort his/her thoughts productively whereas when the thoughts of an individual are disorganized then it becomes difficult for him/her to make a correctchoice andto reach his/her goal.

The advantage of counseling embraces a greater amount of self-awareness and understanding of oneself and others. This develops self-esteem and insight in one's own relationship. It makes one feel better, boost up the confidence, make the goals achievable etc. There is nothing to beashamed if one is taking counseling, rather it the matter of proud since he/she wants to live a happy life and he/she is makingefforts toward it. Counseling expands one's mental health, self-knowledge, well-being and clarity of mind. It gives an individual a fair opportunity to improve one's standard of living and also gifts a complete feeling of positive change that results into amore productive life.

\section{Review of Literature}

Greg Feld man (2010) experimented the study of differential effects of mindful breathing, PMR and loving-kindness meditation on decentering and negative reactions to repetitive thoughts among the students. He found that mindful breathing may help to reduce reactivity to repetitive thoughts. Its consequences help to provide similarly proof of decentering as a capability mechanism that distinguishes mindfulness exercise from different credible pressure-management procedures.

Shahyad Ghonchen (2004) formulated the study of PMR, yoga stretching, and $A B C$ relaxation theory on forty participants were randomly divided in to two groups and taught PMR or yoga stretching exercises. The results suggest the value of supplementing traditional somatic conceptualizations of relaxation with the psychological approach embodied in $A B C$ relaxation theory.

Curran SL. (2010) conducted a study on the effect of Progressive muscle relaxation technique on anxiety state and blood pressure in patient with essential hypertension 40 subjects from a hypertension outpatient clinic received progressive muscle relaxation technique training once in a week and practiced at home daily for four weeks. Progressive muscle relaxation technique significantly enhanced 
their perception of health and in beneficial for patients with level of anxiety.

A study by Baird CL. Sand L. (2009) was conducted of Progressive muscle relaxation technique based on muscle stretching exercise on hundred elderly patients. The study explored the clinical efficacy of the techniques. The results revealed that these procedures are useful in the treatment of neck tension / pain and anxiety. The potential role of stretch-based relaxation technique was effective in the management of anxiety.

Rickard SC. Collier JP. (2009) conducted a study on progressive relaxation training for elderly persons with anxiety. The elderly were exposed to either progressive relaxation procedures, reported significant relaxation effects, showed improvement on measures of personal functioning. The results showed significant positive changes following relaxation training.

\section{Objectives}

1. To study the stress level of college students.

2. To study the effect of progressive muscle relaxation on college students.

3. To study the effect of Talk therapy on college students.

\section{Hypothesis}

"There is a significant effect of progressive muscle relaxation and talk therapy on reducing the stress level of college students."

\section{Test Description}

The standardized stress scalenamed as "Perceived Stress Scale" constructed and standardized bySheldon Cohen (1983) was used in the research. PSS is the most extensively used psychological tool for determining the awareness of stress. It is a measure of the extent to which situations in one's life are appraised as demanding. Items were planned and designed to tap how random, unmanageable, and clogged respondents discover their lives. The scale also includes numerous direct queries about present levels of experienced stress. The PSS was intended for use in society samples with at least junior high school edification. The items are simple to comprehend, and the response options areeasy to gain. Furthermore, the questions are of a universal nature and therefore are comparatively free of content explicit to any subpopulation group. The questions in the PSS ask about thoughts and feelingsat some point in the last month. In each case, respondents are asked how frequently they felt a certain way.

\section{Methodology}

\section{Locale}

The locale of the present research is Udaipur district of Rajasthan state.

\section{Sample}

The sample of the present study consisted of 60college students (30 in each group)randomly selected from a college of Udaipur, Rajasthan.

\section{Method of data collection}

Prior consent was taken from the participants regarding the test to be conducted. After rapport establishment, they were told about the purpose of the research. They were assured that their responses will be kept confidential and will be used for research purpose only.

The following instructions given to them were:

"Here are some general questions to know some basic information about the level of stress. You have to tick mark in front of the statement on any of the five options i.e. always, mostly, sometimes, rarely and never. Please free to give response and take your suitable time for giving response but do attempt all the questions given in the test."

After giving required instructions, participants have completed the test and then scoring was done as score 
5 is given to always, 4 is given to mostly, 3 is given to sometimes, 2 is given to rarely and 1 is given to never. Two groups of 30 samples each were formed: Control and Experimental group. During pre - testing, a standardized scale by Sheldon Cohen (1983) namely 'Perceived Stress Scale'was administered on both the groups. Afterwards, Progressive muscle relaxation and talk therapy was given to the samplesof experimental group but no intervention was given to control group. During post - testing, the above mentioned stress scale was again conducted on both control and experimental groups.

\section{Tabulation and Interpretation}

Table 1.1

\begin{tabular}{|c|c|c|c|c|c|c|c|c|}
\hline & Group & $\mathrm{N}$ & $\begin{array}{l}\mathrm{M} \\
\text { ea } \\
\mathrm{n}\end{array}$ & $\begin{array}{l}\text { Std. } \\
\text { Devi } \\
\text { ation }\end{array}$ & $\begin{array}{l}\text { Std. } \\
\text { Error } \\
\text { Mean }\end{array}$ & $\begin{array}{l}\text { Mean } \\
\text { Diff }\end{array}$ & 't' & $\begin{array}{l}\mathrm{P} \\
\text { valu } \\
\mathrm{e}\end{array}$ \\
\hline$P$ & Control & $\begin{array}{l}3 \\
0\end{array}$ & $\begin{array}{l}32 . \\
47\end{array}$ & 4.032 & 0.736 & \multirow[t]{2}{*}{0.200} & $\begin{array}{l}0.1 \\
87\end{array}$ & \multirow[t]{2}{*}{$\begin{array}{l}0.85 \\
2\end{array}$} \\
\hline re & $\begin{array}{l}\text { Experi } \\
\text { mental }\end{array}$ & $\begin{array}{l}3 \\
0\end{array}$ & $\begin{array}{l}32 . \\
27\end{array}$ & 4.258 & 0.777 & & & \\
\hline
\end{tabular}

As per the above statistical analysis, Table 1.1 shows that the mean and S.D. of control group was calculated as 32.47 and 4.032 whereas the mean and S.D. of experimental group was found to be 32.27 and 4.258 respectively. The 'Mean difference' $t$ ' value and 'P' value was calculated as $0.200,0.187$ and 0.852 respectively. This shows that the difference between control and experimental group on the basis of stress level prior relaxation technique intervention was insignificant at 0.05 level.

Table 1.2

\begin{tabular}{|c|c|c|c|c|c|c|c|}
\hline & $\begin{array}{l}\text { Mea } \\
\mathrm{n}\end{array}$ & $\mathrm{N}$ & $\begin{array}{l}\text { Std. } \\
\text { Deviat } \\
\text { ion }\end{array}$ & $\begin{array}{l}\text { Std. } \\
\text { Error } \\
\text { Mean }\end{array}$ & $\begin{array}{l}\text { Mea } \\
n \\
\text { Diff }\end{array}$ & 't' & $\begin{array}{l}\mathrm{P} \\
\text { valu } \\
\mathrm{e}\end{array}$ \\
\hline Control & 32.4 & 3 & 4.032 & 0.736 & 0.16 & 0.81 & 0.42 \\
\hline Pre & 7 & 0 & & & 7 & 7 & 0 \\
\hline
\end{tabular}

\begin{tabular}{|l|l|l|l|l|l|l|l|}
\hline $\begin{array}{l}\text { Control } \\
\text { Post }\end{array}$ & $\begin{array}{l}32.3 \\
0\end{array}$ & 3 & 3.621 & 0.661 & & & \\
\hline
\end{tabular}

Table 1.2 shows that the mean value and S.D. of Pre testing in Control group was calculated as 32.47 and 4.032 whereas the mean value and S.D. of Post testing in Control group was found to be 32.30 and 3.621 respectively. The 'Mean difference' $t$ ' value and ' $P$ ' value was calculated as $0.167,0.817$ and 0.420 respectively. This clearly shows that difference between Pre and Post testing conducted on Control group on the basis of stress level was also found insignificant at 0.05 level.

\section{Table 1.3}

\begin{tabular}{|c|c|c|c|c|c|c|c|}
\hline & $\begin{array}{l}\mathrm{Me} \\
\text { an }\end{array}$ & $\mathrm{N}$ & $\begin{array}{l}\text { Std. } \\
\text { Devia } \\
\text { tion }\end{array}$ & $\begin{array}{l}\text { Std. } \\
\text { Error } \\
\text { Mean }\end{array}$ & $\begin{array}{l}\text { Me } \\
\text { an } \\
\text { Dif } \\
\text { f }\end{array}$ & 't' & $\begin{array}{l}\mathrm{P} \\
\text { valu } \\
\mathrm{e}\end{array}$ \\
\hline $\begin{array}{l}\text { Experiment } \\
\text { al Pre }\end{array}$ & $\begin{array}{l}32 . \\
27\end{array}$ & $\begin{array}{l}3 \\
0\end{array}$ & 4.258 & 0.777 & $\begin{array}{l}9.2 \\
33\end{array}$ & $\begin{array}{l}26.2 \\
84\end{array}$ & $\begin{array}{l}0.00 \\
0\end{array}$ \\
\hline $\begin{array}{l}\text { Experiment } \\
\text { al Post }\end{array}$ & $\begin{array}{l}23 . \\
03\end{array}$ & $\begin{array}{l}3 \\
0\end{array}$ & 3.908 & 0.714 & & & \\
\hline
\end{tabular}

According to Table 1.3, the mean value and S.D. of Pre testing in Experimental group was calculated as 32.27 and 4.258 whereas the mean value and S.D. of Post testing in Experimental group was found to be 23.03 and 3.908 respectively. The 'Mean difference'and' $t$ ' value was found to be 9.233 and 26.284respectively. This clearly depicts that difference between Pre and Post testing conducted on Experimental group on the basis of stress level was also found significant at 0.01 level. The scores shows that during Pre testing, the stress level of college students was high but after the counseling programme was given, the Post testing showed 
Nikhil Chaudhary, Dr. Tarun Kumar Sharma Int J Sci Res Sci Technol. January-February-2020 ; 7 (1) : 314-320

significantly low level of stress among college students. 
Table 1.4

\begin{tabular}{|c|c|c|c|c|c|c|c|c|}
\hline & Group & $\mathrm{N}$ & $\begin{array}{l}\mathrm{M} \\
\text { ea } \\
\mathrm{n}\end{array}$ & $\begin{array}{l}\text { Std. } \\
\text { Devi } \\
\text { ation }\end{array}$ & $\begin{array}{l}\text { Std. } \\
\text { Error } \\
\text { Mea } \\
\text { n }\end{array}$ & $\begin{array}{l}\text { Mean } \\
\text { Diff }\end{array}$ & 't' & $\begin{array}{l}\mathrm{P} \\
\text { valu } \\
\mathrm{e}\end{array}$ \\
\hline \multirow{2}{*}{$\begin{array}{l}\text { Po } \\
\text { st }\end{array}$} & Control & $\begin{array}{l}3 \\
0\end{array}$ & $\begin{array}{l}32 . \\
30\end{array}$ & 3.621 & 0.661 & \multirow[t]{2}{*}{9.267} & $\begin{array}{l}9.5 \\
26\end{array}$ & \multirow[t]{2}{*}{$\begin{array}{l}0.00 \\
0\end{array}$} \\
\hline & $\begin{array}{l}\text { Experi } \\
\text { mental }\end{array}$ & $\begin{array}{l}3 \\
0\end{array}$ & $\begin{array}{l}23 . \\
03\end{array}$ & 3.908 & 0.714 & & & \\
\hline
\end{tabular}

Table 1.4 shows that the mean and S.D. of Post testing in Control group was calculated as 32.30 and 3.621 whereas the mean and S.D. of Post testing in Experimental group was found to be 23.03 and 3.908. The 'Mean difference'and' $t$ ' value was found to be 9.267 and 9.526 respectively. This again shows that the difference between Post Control and Post Experimental group was found to be significant as 0.01 level which means that the counseling programme reduced the stress level of the group on which it was applied.

\section{v. CONCLUSION}

1. There is no significant difference between Pre Control and Pre Experimental group.

2. There is no significant difference between Pre Control and Post Control group.

3. There is a significant difference between Pre Experimental and Post Experimental group.

4. There is a significant difference between Post Experimental and Post Experimental group.

\section{REFERENCES}

[1]. Greg Feld man, Jeff Greeson, Joanna Senville Differential effects of mindful breathing, Progressive Muscular Relaxation, and lovingkindness meditation on decentering and negative reactions to repetitive thoughts: Behavioral Research and Therapy, Science Direct: Oct. 2010, vol.48, issue 10, pp.10021011.

[2]. Shahyad Ghonchen and Jonathan C. Smith Progressive Muscular Relaxation, yoga stretching, and $A B C$ relaxation Theory: Journal of Clinical Psychology vol.60, issue 1, pp 131136.

[3]. Curran SL. Clinical efficacy of progressive muscle relaxation technique. Nursing practice. 2 (5); 2010. pp $154-157$.

[4]. Baird CL. Sand L. Effectiveness of guided imaginary with progressive muscle relaxation on elderly pain management. Pavi management nursing. 5 (3); 2009. pp $94-104$.

[5]. Rickard SC. Collier JP. Relaxation training and side effects. Journal of clinical psychology. 45 (3); 2009. pp $446-450$.

\section{Cite this article as :}

Nikhil Chaudhary, Dr. Tarun Kumar Sharma, "A Study of Stress Reduction Through PMR and Talk therapy Among College Students", International Journal of Scientific Research in Science and Technology (IJSRST), Online ISSN : 2395-602X, Print ISSN : 2395-6011, Volume 7 Issue 1, pp. 314-320, January-February 2020. Available at doi : https://doi.org/10.32628/IJSRST16267

Journal URL : https://ijsrst.com/IJSRST16267 